\title{
ANALISIS TINGKAT PENDAPATAN PEDAGANG SAYUR-SAYURAN DAUN DI PASAR SORE SIRIWINI DISTRIK NABIRE KABUPATEN NABIRE
}

\author{
Simon Matakena \\ Staf Pengajar Faperta USWIM-Nabire, $\boldsymbol{e}$-mail : -
}

\begin{abstract}
ABSTRAK
Pedagang sayur-sayuran yang melaksanakan aktifitas sehari-harinya pada pasar sore Siriwini Distrik Nabire Kabupaten Nabire sebagian besar merupakan kegiatan ekonomi yang dilakukan oleh para ibu rumah tangga yang dijadikan sebagai aktifitas sampingan dengan tujuannya untuk meningkatkan pendapatan keluarga. Penelitian yang dilakukan dengan tujuan untuk mengetahui tingkat pendapatan dan kelayakan usaha pedagang serta faktor-faktor yang mempengaruhi tingkat pendapatan ini dilakukan pada bulan Maret sampai dengan April 2009 dan berlokasi pada pasar sore Siriwini Kabupaten Nabire. Berdasarkan hasil penelitian, dimana nilai R/C (Return Cost Ratio) untuk masing-masing komoditi sayur-sayuran daun yang diperdagangkan yaitu untuk Kangkung sebesar 1,63, untuk bayam sebesar 1,65 dan sayur sawi sebesar 1,65 dimana rata-rata nilai $R / C$ adalah 1,64 dimana lebih besar dari 1 maka layak diusahakan karena menguntungkan bagi pedagang. Karena rata-rata nilai $R / C$ lebih besar dari 1 serta layak diusahakan dan menguntungkan, maka otomatis penghasilan pedangan menguntungkan dan dapat meningkatkan pendapatan rumah tangga pedagang sehingga kesejahteraan rumah tangga pedagangpun dapat ditingkatkan. Dari hasil analisa regresi untuk komoditi kangkung variabel umur dan jumlah tanggungan memiliki hubungan yang positif dengan pendapatan dan untuk variabel pendidikan serta lama berdagang memiliki hubungan yang negatif dengan pendapatan.
\end{abstract}

Kata Kunci : Pedagang, Nabire, sayur-sayuran.

\section{PENDAHULUAN}

\subsection{Latar Belakang}

Pertanian mempunyai kontribusi yang besar dalam proses pembangunan ekonomi. Kontribusi pertanian terhadap pembangunan ekonomi pertanian negara yang mana mencakup kontribusi produksi, kontribusi pasar, kontribusi faktor produksi dan kontribusi devisa (Widodo, $1993: 2$ ).

Semakin pentingnya pertanian dalam pembangunan Indonesia, terutama dalam rangka tujuan swasembada pangan, maka komoditas pertanian penting untuk mendapat perhatian khusus dari pemerintah dalam mengatasi masalah-masalah pertanian. Masalah tersebut juga menyangkut masalah ekonomi pertanian dalam hubungannya dengan analisis perekonomian pertanian.

Komoditas pertanian memiliki karakteristik seperti bersifat musiman (siclic fluctuations), mudah rusak (perishable), kaku (bulky) dan membutuhkan tempat (volummenous). Hal ini yang menjadi masalah bagi petani, maka pembangunan ekonomi pertanian 
memegang peranan penting dalam memberikan kontribusi bagi pembangunan perkembangan ekonomi pertanian.

Pembangunan pertanian sebagai salah satu pembangunan ekonomi di Indonesia yang bertujuan : Meningkatkan kesejahteraan masyarakat tani di pedesaan, ini dapat dicapai bila pendapatannya dapat ditingkatkan dari sumber pendapatan dari pertanian yang diproduksi petani dijual kepada konsumen.

Dilihat dari pembangunan pertanian, khususnya tanaman pangan di Kabupaten Nabire perlu ditingkatkan dalam rangka mencapai swasembada pangan serta meningkatkan pendapatan masyarakat dan perbaikan gizi melalui penganekaragaman jenis bahan pangan dan masih diarahkan pada upaya meningkatkan produksi palawija dan hortikultura yang penekanannya terutama pada tanaman sayur-sayuran daun yang merupakan salah satu bagian produksi hortikultura yang perlu ditumbuh kembangkan menjadi agribisnis dalam rangka memanfaatkan peluang yang ada berupa iklim yang bervariasi, lahan yang subur dan tersedia tenaga kerja. Prospek pengembangan usaha tani sayur-sayuran daun ini cukup cerah karena permintaan akan komoditi ini cukup tinggi.

Penjualan merupakan kegiatan yang bertujuan untuk mencari atau mengusahakan agar ada pembeli atau permintaan pasar yang cukup baik atau banyak terhadap barang dan jasa yang dipasarkan pada tingkat harga yang menguntungkan. Penjualan juga merupakan perencanaan tentang cara-cara atau pola penjualan yang bagaimana yang dapat menjamin adanya kemantapan pasar dari barang dan jasa yang diusahakan (Limbong, 1987).

Pedagang sayur-sayuran daun yang ada di pasar sore Seriwini beragam, baik orang muda dan orang dewasa serta tidak melihat orang Papua dengan non Papua tetapi semuanya menjual sayur-sayuran diantaranya sayur buah maupun sayur daun sesuai dengan dagangan yang dibawa untuk berjualan dengan konsep atau strateginya masing-masing untuk menjual harga pemasaran tidak sesuai dengan harga persaingan pemasarannya tetapi disesuaikan dengan harga pemasaran yang berlaku pada saat itu, atau naik turun harga sayur-sayuran daun di Pasar Sore Siriwini.

Pada lokasi penelitian yaitu di Pasar Sore Siriwini, para pedagang sebagian besar adalah para ibu rumah tangga, mereka rajin dan bersemangat untuk melakukan aktifitas jualan sayuran ini, sehingga ada yang setiap harinya selalu berdagang sementara para suaminya juga bekerja ada yang sebagai pegawai negeri maupun swasta serta petani dan nelayan, dengan sendirinya dapat dilihat bahwa motivasi kerja yang tinggi ini dadasari pada penghasilan yang menguntungkan dan layak sehingga semangat kerjapun meningkat. Disamping itu umur dan tingkat pendidikan dari pedagang yang bervariasi serta jumlah anggota keluarga atau jumlah tanggungan dalam rumah tangga juga beragam, dimana banyaknya jumlah anggota rumah tangga mengakibatkan kebutuhan dalam rumahpun meningkat sehingga mau tidak mau harus mencari tambahan pendapatan rumah tangga dan ini merupakan faktor yang mempengaruhi para pedagang dalam hal ini para ibu rumah tangga untuk lebih giat berusaha dengan jalan berdagang sayur-sayuran di Pasar Sore Siriwini Distrik Nabire Kabupaten Nabira.

Menurut pengakuan pedagang sayursayuran pada pasar sore Seriwini Kabupaten Nabire sangat menguntungkan dan dapat meningkatkan penghasilan keluarga mereka, oleh sebab itu penulis tertarik untuk melihat pedagang sayursayuran khususnya pedagang sayuran daun karena para pedagangnya bervariasi baik pendatang maupun pribumi dan ada yang merupakan pedagang pengecer dan ada juga pedagang yang menjual hasil pertaniannya sendiri. 


\subsection{Permasalah}

Berdasarkan latar belakang diatas
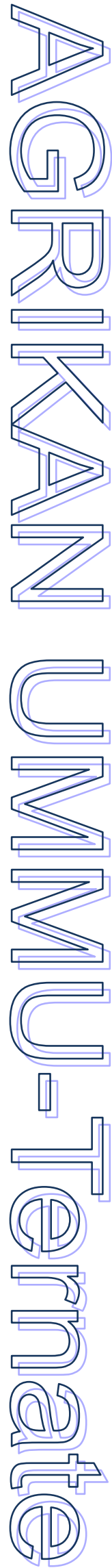

\subsection{Tujuan Penelitian}

Tujuan dalam penelitian ini adalah untuk :

1. Mengetahui besarnya pendapatan yang diterima oleh pedagang sayur-sayuran daun.

2. Mengetahui faktor-faktor yang mempengaruhi pendapatan pedagang sayur-sayur daun.

\subsection{Kegunaan Penelitian}

Adapun yang menjadi kegunaan dalam penelitian ini adalah :

1. Dapat mengetahui bagaimana petani sayur-sayuran daun dapat menambah pendapatan dalam memenuhi kebutuhan keluarganya.

2. Dapat menjadi bahan acuan bagi peneliti lain yang topiknya pilihan dengan penelitian ini.

3. Dapat menjadi bahan masukan bagi Pemerintah Daerah dalam mengambil kebijakan.

\subsection{Hipotesis}

Berdasarkan latar belakang masalah dan tujuan penelitian maka hipotesis yang dapat diangkat sebagai dasar dalam pemecahan masalah adalah sebagai berikut :

1. Pendapatan yang diperoleh oleh pedagang sayur-sayuran daun di Pasar Sore Siriwini Distrik Nabire Kabupaten Nabire menguntungkan dan layak diusahakan.
2. Umur, tingkat pendidikan, pengalaman berdagang, dan jumlah tanggungan dalam rumah tangga, mempengaruhi pendapatan pedagang sayur-sayuran daun di pasar Sore Siriwini.

\section{METODOLOGI}

\subsection{Metode Penelitian}

Metode yang digunakan dalam penelitian ini adalah metode deskriptif. Yang mana mengggambarkan keadaan kondisi suatu tempat pada saat melakukan penelitian

\subsection{Metode Penentuan Sampel}

Penentuan sampel pedagang dilakukan secara acak sederhana (Simple Random Sampling), $30 \%$ dari jumlah pedagang sayuran daun di Pasar Sore Kelurahan Siriwni, atau sebanyak 18 responden.

\subsection{Metode Pengumpulan Data}

Data yang dikumpulkan dalam penelitian ini adalah data primer dan data sekunder. Data primer diperoleh dari hasil survey melalui kegiatan wawancara dan pengisian daftar pertanyaan (kuseioner) pedagang, sedangkan data sekunder diperoleh dari Kantor Kelurahan Siriwini dan instansi-instansi lain yang terkait dengan penelitian ini.

\subsection{Kerangka Analisa}

Untuk menguji hipotesis pertama yaitu mengetahui besarnya pendapatan yang diterima dari harga jual yang berlaku ditingkat petani, maka digunakan rumus sebagai berikut :

$$
\mathrm{Pd}=\mathrm{TR} 1-\mathrm{TC} 1
$$

Dimana :

Pd = Pendapatan Pedagang Sayuran

TR = Total Penerimaan

$\mathrm{TC}=$ Total Biaya

Kemudian digunakan untuk menilai kelayakan usaha tani, dimana indikatornya sebagai berikut :

$$
\mathrm{RCR}=\mathrm{TR} / \mathrm{TC}
$$


Dimana :

$$
\begin{aligned}
\mathrm{RCR}= & \text { Return} / \text { Revenue and Cost } \\
& \text { Rasio } \\
\mathrm{TR}= & \text { Total Penerimaan (Total } \\
& \text { Revenue) } \\
\mathrm{TC}= & \text { Total Biaya Produksi (Total } \\
& \text { Cost) }
\end{aligned}
$$

Kriteria keuntungan dengan indikator ini adalah : RCR $\geq 1$ dianggap layak, sedangkan RCR < 1dianggap tidak layak ( Sitorus, $1993: 21$ ).

Dan untuk menguji hipotesis kedua menggunakan persamaan Regresi berganda dengan bentuk persamaannya sebagai berikut:

$$
Y=a+b_{1} X_{1}+b_{2} X_{2}+b_{3} X_{3}+b_{4} X_{4} \ldots(3)
$$

Dimana ;

$$
\begin{aligned}
\mathrm{Y}= & \text { Pendapatan } \\
\mathrm{a}= & \text { Konstanta } \\
\mathrm{b}= & \text { Koefisien Regresi } \\
\mathrm{X}_{1}= & \text { Umur } \\
\mathrm{X}_{2}= & \text { Tingkat Pendidikan } \\
\mathrm{X}_{3}= & \text { Pengalaman Berdagang } \\
\mathrm{X}_{4}= & \text { Jumlah Tanggungan dalam } \\
& \text { Rumah Tangga }
\end{aligned}
$$

\subsection{Waktu dan Tempat Penelitian}

Pelaksanaan Penelitian ini berlangsung selama dua bulan dari bulan Maret sampai dengan April 2009, dan berlokasi pada pasar sore Siriwini Distrik Nabire Kabupaten Nabire Propinsi Papua.

\section{HASIL DAN PEMBAHASAN \\ 3.1. Analisis Pendapatan 3.1. 1. Biaya Produksi}

Kegiatan para pedagang sayuran di pasar sore siriwini hanya memerlukan biaya produksi yang meliputi biaya transportasi selama berjualan, biaya retribusi atau pajak penggunaan tempat untuk berjualan selama aktifitas berjualan dilaksanakan serta modal untuk beli sayuran yang diperdagangkan. Kegiatan pedagang ini tidak memerlukan biayabiaya lainnya seperti biaya tenaga kerja atau buruh karena para pedagang sendiri yang memperdagangkan sayurannya.
Biaya produksi merupakan faktor yang sangat menentukan kelangsungan proses produksi, mengingat biaya adalah pengorbanan-pengorbanan yang mutlak harus diadakan, dikeluarkan agar dapt diperoleh suatu hasil (Wasis, 1992). Biaya yang dikeluarkan seorang pedagang dalam proses produksi sehingga membawanya menjadi produk disebut biaya produksi yang meliputi biaya tetap dan biaya variabel. Adapun biaya tetap dalam usaha pedagang sayuran di pasar sore siriwini ini antara lain biaya retribusi pasar. Sedangkan biaya variabel meliputi harga beli sayuran yang dipedagangkan serta biaya transportasi yang dikeluarkan oleh pedagang itu sendiri. Untuk lebih jelasnya dapat dilihat pada tabel 1 berikut ini, tentang rata-rata biaya produksi, penerimaan dan pendapatan dari pedagang sayur-sayuran di pasar sore siriwini.

Berdasarkan hasil analisa pada tabel 1 , rata-rata biaya produksi atau yang biaya dikeluarkan oleh pedagang sayur-sayuran berbeda namun perbedaannya tidak terlalau menyolok dimana sayur kangkung sebesar Rp 788.000, sayur bayam sebesar Rp 738.667 dan untuk sayuran sawi rata-rata biaya pengeluaran sebesar Rp 746.000. dari ketiga komoditi sayuran daun yang diperdagangkan oleh pedagang sayurasayuran di pasar sore Siriwini tidak berbeda jauh disebabkan karena dari 18 responden yang dijadikan sampel semuanya menjual ketiga jenis sayur ini dan biaya retribusi sama untuk setiap harinya. Yang menjadi perbedaan yaitu lamanya waktu atau jumlah hari kerja dalam sebulan yang berbeda serta jumlah sayur yang diperdagangkan juga berbeda.

\subsubsection{Harga Jual}

Harga merupakan indicator yang penting bagi penjual maupun pembeli dalam melakukan suatu perdagangan, dalam hal ini perdagangan sayur-sayuran daun di pasar sore siriwini distrik nabire kabupaten Nabire. Bagi pedagang yang dalam hal ini merupaka produsen harga menjadi pedoman untuk melaksanakan produktifitas dan bagi pembeli harga 
merupakan keputusan akhir untuk membeli hasil produksi. Hasil penelitian menunjukan bahwa antara pedagang sayursayuran daun yang satu dengan yang lainnyatidak terjadi perbedaan harga jual, ini dikarenakan harga beli per ikat satu komoditi sayuran daun baik kangkung, bayam maupun sawi sama yaitu Rp 1.500.
Sementara harga jual juga sama yaitu $\mathrm{Rp}$ 3.000,- per ikat, sehingga tidak terjadi selisih harga antar pedagang, hanyalah para pelanggan dari pedagang inilah yang menentukan banyak sedikitnya pedagang menjual sayuran mereka.

Tabel 1. Rata-rata Biaya Produksi/Pengeluaran, Penerimaan, Pendapatan dan R/C selama Sebulan Pedagang Sayur-Sayuran di Pasar Sore Siriwini Distrik Nabire Kabupaten Nabire

\begin{tabular}{llrrrr}
\hline No & $\begin{array}{c}\text { Komoditi } \\
\text { Sayuran }\end{array}$ & $\begin{array}{c}\text { Biaya } \\
\text { Produksi }\end{array}$ & $\begin{array}{c}\text { Penerimaan } \\
\text { (RP) }\end{array}$ & \multicolumn{1}{c}{$\begin{array}{c}\text { Pendapatan } \\
\text { (RP) }\end{array}$} & \multicolumn{1}{c}{ R/C } \\
\hline 1 & Kangkung & 788.000 & 1.288 .000 & 500.000 & 1.63 \\
2 & Bayam & 738.667 & 1.216 .000 & 477.333 & 1.65 \\
3 & Sawi & 746.000 & 1.230 .666 & 484.667 & 1.65 \\
\hline & Rata-rata & $757.555,67$ & $1.244 .888,67$ & $487.333,33$ & 1.643 \\
\hline
\end{tabular}

Sumber : Data Primer, 2008.

\subsubsection{Pendapatan Pedagang Sayur- Sayuran Daun}

Pendapatan merupakan hasil dari pengurangan penerimaan dengan total pengeluaran atau total produksi yang dihitung dalam satu bulan. Bisa dikatakan juga keuntungan yang diperoleh para pedagang sayur-sayuran daun selama satu bulan.

Hasil penelitian menunjukkan bahwa pendapatan setiap pedagang dihitung per hari kerja dan hari kerja pedagang dilihat dalam sebulan sehingga mendapat pendapatan pedagang selama satu bulan. Rata-rata pendapatan pedagang sayur kangkung sebesar Rp 500.000,- per bulan. Ini menunjukkan bahwa komoditi kangkung cukup menguntungkan bila diusahakan atau dijual oleh pedagang sayur di pasar sore siriwini. Sementara untuk komoditi bayam dan sawi rata-rata pendapatan setiap bulannya adalah $\mathrm{Rp}$ 477,333,- dan $\mathrm{Rp}$ 484.667,- . hal ini menunjukkan bahwa antara ketiga komoditi sayur-sayuran yang diperdagangkan di pasar sore cukup menguntungkan. Dan dapat ditingkatkan apabila ada keinginan dari para pedagang untuk menambah jumlah dagangan mereka, namun berdasarkan pengakuan para pedagang kegiatan berjualan yang mereka lakukan di pasar sore merupakan mata pencaharian tambahan dimana masingmasing memiliki pekerjaan tetap yang mereka lakukan dipagi hari sampai siang hari, jadi dengan jumlah yang didapat sudah cukup untuk membantu atau meningkatkan penghasilan keluarga para pedagang.

\subsubsection{Analisis Return Cost Ratio (RCR)}

Analisis R/C dilakukan untuk mengetahui perbandingan (ratio) antara penerimaan (output) dengan biaya-biaya yang dikeluarkan (input) oleh pedagang sayuran dipasar sore siriwini, sehingga apakah layak untuk diusahakan atau tidak. Berdasarkan kriteria penilaian dimana nilai $\mathrm{R} / \mathrm{C}$ lebih kecil dari satu maka tidak layak diusahan karena pedagang akan mengalami kerugian atau nial R/C sama dengan satu maka berada pada kondisi impas (Break Event Point/BEP) atau tidak untuk dan tidak rugi pulan. Sementara apabila nilai $\mathrm{R} / \mathrm{C}$ lebih dari satu maka layak diusahakan karena pedagang mengalami keuntungan.

Berdasarkan hasil analisa rata-rata nilai $\mathrm{R} / \mathrm{C}$ untuk sayuran kangkung adalah sebesar 1,64 (tabel 5). ini berarti sayur kangkung layak diusahakan karena memiliki nilai $\mathrm{R} / \mathrm{C}$ lebih dari satu maka 
pendapatan yang diperoleh menguntungkan. Nilai R/C ini sebesar 1,64 menunjukkan bahwa jika peningkatan input atau pengeluaran sebesar Rp 1 maka output atau pendapatan akan meningkat sebesar Rp 1,64. Untuk sayuran bayam yang diperdagangkan berdasarkan hasil analisis menunjukkan nilai $\mathrm{R} / \mathrm{C}$ sebesar 1,65 ini berarti bahwa sayuran bayam juga layak diusahakan dan menguntungkan dimana apabila kenaikan input (pengeluaran) sebesar $\mathrm{Rp} 1$ maka akan meningkat output (pendapatan) sebesar Rp 1,65. Dan pada sayuran sawi juga menguntungkan untuk diusahakan dengan nilai $\mathrm{R} / \mathrm{C}$ sebesar 1,65 ini menunjukkan bahwa penambahan $\mathrm{Rp} 1$ pengeluaran akan meningkatkan pendapatan sebesar $\quad \mathrm{Rp}$ 1,65 (tabel 5). Dengan demikian usaha dagang sayur-sayuran ini menguntungkan dan layak untuk diusahakan karena nilai $\mathrm{R} / \mathrm{C}$ nya lebih dari satu, dengan pendapatan yang menguntungkan ini maka dengan sendirinya para pedagang yang sebagian besar para ibu rumah tangga dapat meningkatkan pendapatan rumah tangga mereka.

\subsection{Hubungan Umur, Tingkat Pendidikan, Pengalaman Berdagang dan Jumlah Tanggungan dengan Pendapatan Pedagang Sayur-Sayuran}

Hubungan umur, tingkat pendidikan, pengalaman berdagang dan jumlah tanggungan dalm rumah tangga dengan pendapatan pedagang sayur-sayuran pada pasar sore Siriwini Distrik Nabire Kabupaten Nabire pada penelitian ini dilihat berdasarkan masing-masing komoditi sayur yang diperdagangkan yaitu sayuran kangkung, bayam dan sawi

Berdasarkan hasil penelitian yang dilakukan pada pasar sore Siriwini Distrik Nabire Kabupaten Nabire terlihat bahwa ada hubungan antara umur, tingkat pendidikan, pengalaman berdagang dan jumlah tanggungan berpengaruh terhadap tinggak pendapatan pedagang sayursayuran yang mana berdasarkan hasil analisis regresi untuk masing-masing komoditi sayur yang dijual antara lain kangkung, bayam dan sawi memiliki nilai yang berbeda baik positif maupun negatif. Selengkapnya dapat dilihat pada tabel berikut ini :

Tabel 2. Hasil Analisi Regresi Untuk masing-masing komoditi Sayur yang Dijual di Pasar Sore Siriwini Distri Nabire Kabupaten Nabire

\begin{tabular}{lccc}
\hline \multirow{2}{*}{ Analisis regresi } & \multicolumn{3}{c}{ Komoditi } \\
\cline { 2 - 4 } & Kangkung & Bayam & Sawi \\
\hline Constanta & 87,651 & 15,569 & 587,554 \\
X1 (umur) & 11,548 & 14,366 & $-3,791$ \\
X2 (pendidikan) & $-7,877$ & 25,309 & $-16,118$ \\
X3(lama berdagang) & $-8,741$ & $-23,016$ & $-5,774$ \\
X4 (jml tanggungan) & 29,871 & 17,912 & 15,312 \\
\hline
\end{tabular}

\subsubsection{Komoditi Kangkung}

Berdasarkan perhitungan regresi berganda yang dituangkan dalam tabel 2 terlihat untuk komoditas kangkung dapat disusun hasil hitungan regresi sebagai berikut :

$\mathrm{Y}=87,651+11,548 \mathrm{X}_{1}-7,877 \mathrm{X}_{2}-$ $8,741 \mathrm{X}_{3}+29,871 \mathrm{X}_{4}$

Dari persamaan diatas dapat dijelaskan bahwa ; pada komoditi kangkung dengan nilai konstanta sebesar 87,651 , berarti bahwa pendapatan dari hasil penjualan kangkung tidak terjadi perubahan apabila variabel-variabel lainnya yang mempengaruhi pendapatan dari penjualan kangkung tidak mengalami perubahan dengan asumsi cateris paribus. Dan apabila terjadi perubahan pada variabel-variabel yang mempengaruhi pendapatan maka nilai konstanta tetap pada 
87,651 dan nilai variabel-variabel lain berubah. Untuk nilai koefisien pada variabel $\mathrm{X}_{1}$ yaitu sebesar 11,548, menunjukan bahwa faktor umur mempunyai pengaruh yang positif terhadap peningkatan pendapatan pedagang kangkung dimana kenaikan 1 unit usia akan meningkatkan pendapatan sebesar $\mathrm{Rp}$ 11,548 ,- ini berarti bahwa umur atau usia dari pedagang berpengaruh terhadap pendapatan yang mana semakin tinggi umur berarti semakin berpengalaman dalam berdagang sehingga pedangan sudah banyak memiliki langganan serta memiliki kiat-kiat dalam berdagang sehingga pendapatannya juga meningkat jika dibandingkan dengan pedagang yang berusia muda dimana variabel-variabel lain tetap.

Sementara untuk koefisien nilai $\mathrm{X}_{2}$ dan $\mathrm{X}_{4}$ yaitu pendidikan dan pengalaman berdagang masing masing memiliki nilai negatif yaitu - 7,877 dan - 8,741, hal ini menunjukan hubungan yang negatif antara pendapatan dengan pendidikan dan lamanya berdagang. Hasil perhitungan regresi $\mathrm{X}_{2}$ dan $\mathrm{X}_{4}$ bermakna peningkatan pendidikan dan lamanya berdagang sebesar 1 unit akan menurun pendapatan sebesar Rp 7,877 dan Rp 8,741. Tingkat pendidikan dan lamanya berdagang berpengaruh terbalik dengan pendapatan. Hal ini dapat dilihat bahwa para pedagang memiliki pendidikan yang rata-rata sangat rendah sementara pendapatan pedagang diatas UMR Propinsi Papua dengan sendirinya pendidikan tidak mempengaruhi pendapatan begitu juga dengan lamanya berdagang. Sementara asumsi untuk variabel-variabel lainnya konstan (cateris paribus).

Dan untuk koefisien $\mathrm{X}_{4}$ yaitu jumlah tanggungan dalam keluarga pedagang berpengaruh positif yaitu sebesar 29,871 yang bermakna kenaikan 1 unit tanggungan keluarga maka pendapatan akan meningkat sebesar Rp 29,871,-- hal ini menunjukan bahwa semakin besar jumlah tanggungan maka para pedagang akan berusaha untuk meningkatkan pendapatannya guna memenuhi kebutuhan hidup keluarga. Baik dengan jalan meningkatkan jumlah barang dagangan maupun jumlah jenis barang yang diperdagangkan dalamhal ini sayursayuran yang merupakan komoditi dagangan dalam penelitian ini.

\subsubsection{Komoditi Bayam}

Berdasarkan perhitungan regresi berganda yang dituangkan dalam tabel 16 terlihat untuk komoditas kangkung dapat disusun hasil hitungan regresi sebagai berikut : $\quad \mathrm{Y}=15,569+14,366 \mathrm{X}_{1}+$ $25,309 X_{2}-23,016 X_{3}+17,912 X_{4}$

Dari persamaan diatas dapat dijelaskan bahwa ; pada komoditi kangkung dengan nilai konstanta sebesar 15,569 , berarti bahwa pendapatan dari hasil penjualan kangkung tidak terjadi perubahan apabila variabel-variabel lainnya yang mempengaruhi pendapatan dari penjualan kangkung tidak mengalami perubahan dengan asumsi cateris paribus. Dan apabila pendapatan berubah karena dipengaruhi oleh variabel-variabel yang lain maka nilai konstanta tetap pada 15,569 .

Untuk koefisien variabel $\mathrm{X}_{1}, \mathrm{X}_{2}$ dan $\mathrm{X}_{4}$ memiliki nilai positif yang masingadalah untuk variabel umur 14,569 . untuk tingkat pendidikan 25,309 dan untuk variabel jumlah tanggungan sebesar 17,912. ini bermakna bahwa kenaikan 1 unit usia pendapatan akan meningkat $\mathrm{Rp}$ 14,569,- variabel lain tetap, dan apabila kenaikan 1 unit pendidikan pendapatan akan meningkat $\mathrm{Rp} \mathrm{25,} \mathrm{309,-} \mathrm{variabel}$ lainnya tetap, sedangkan 1 unit tanggungan naik akan memberi peningkatan pendapatan sebesar Rp 17,912 dimana variabel-variabel lainnya tetap. Dan untuk koefisien variabel $\mathrm{X}_{3}$ memiliki nilai negatif yang berarti jika peningkatan 1 unit lamanya berdagang maka pendapatan akan menurun sebesar Rp 23,016,- hal ini terjadi karena nilai koefisien negatif sehingga pendapatan dengan lamanya berdagang berhubungan negatif tau terbalik, sementara variabel-variabel lainnya dalam keadaan cateris paribus. 


\subsubsection{Komoditi Sawi}

Berdasarkan perhitungan regresi
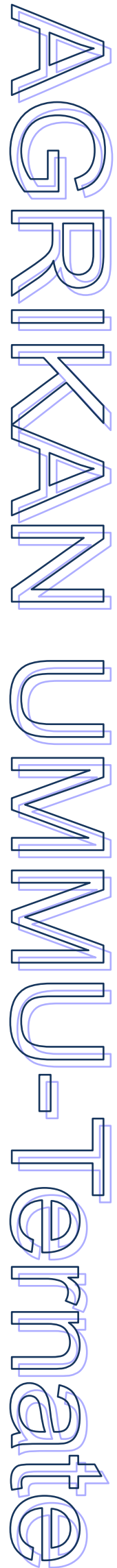

1. Berdasarkan hasil penelitian, dimana nilai R/C (Return Cost Ratio) untuk masing-masing komoditi sayursayuran daun yang diperdagangkan yaitu untuk Kangkung sebesar 1,63, untuk bayam sebesar 1,65 dan sayur sawi sebesar 1,65 dimana rata-rata nilai $\mathrm{R} / \mathrm{C}$ adalah 1,64 dimana lebih besar dari 1 maka layak diusahakan karena menguntungkan bagi pedagang.

2. Karena rata-rata nilai $\mathrm{R} / \mathrm{C}$ lebih besar dari 1 serta layak diusahakan dan menguntungkan, maka otomatis penghasilan pedangan menguntungkan dan dapat meningkatkan pendapatan rumah tangga pedagang sehingga kesejahteraan rumah tangga pedagangpun dapat ditingkatkan.

3. Dari hasil analisa regresi untuk komoditi kangkung variabel umur dan jumlah tanggungan memiliki hubungan yang positif dengan pendapatan dan untuk variabel pendidikan serta lama berdagang memiliki hubungan yang negatif dengan pendapatan. Untuk komoditi bayam umur, pendidikan dan jumlah tanggungan berhubungan positif dan lama berdagang berhubungan negatif dengan pendapatan sedangkan untuk komoditi sawi umur,pendidikan dan lama berdagang berhubungan negatif dengan pendapatan serta jumlah tanggungan berhubungan positif dengan tingkat pendapatan.

4. Hubungan positif berarti peningkatan satu unit sebuah variebal akan mempengaruhi kenaikan satu rupiah pendapatan dengan asumsi variabel lain cateris paribus . sementara untuk hubungan negatif kenaikan satu unit variabel akan menurunkan pendapatan stu rupiah dengan variabel lainnya tetap (cateris paribus) 


\section{DAFTAR PUSTAKA}

Angipora, 1999. Ekonomika Pertanian, Penerbit, Penebar Swadaya,Jakarta

Anonim, 2008. Nabire Dalam Angka. Badan Pusat Statistik Kabupaten Nabire. Papua.

Beirerlein, 1991.Pengantar Teori Ekonomi dan Kasus, Abd.Rahim, Jakarta

David. W. D dan P. E. Steven, 1987. Managemen Agribisnis. Erlangga, Jakarta. Ahli Bahasa Rochidayat G. S dan A. Sirait, 1989.

Downey. W. David dan Steven. P. Erickson, 1992. Manajemen Agribisnis Erlangga, Jakarta.

Hamid. A. K, 1972. Tataniaga Pertanian Fakultas Pertanian. IPB, Bogor.

Hanafiah. A. M dan A. M. Saefuddin 1986. Tataniaga Hasil Perikanan. UI, Jakarta.

Hendriks, 1998. Analisis Sistem Pemasaran Komoditi Kopi di Dusun Tanah Goyang Desa Lokki Kecamatan Seram Barat Kabupaten Maluku Tengah. (Skripsi) Fakultas Pertanian Universitas Pattimura, Ambon.

Kartasapoetra, 1986. Managemen Pertanian (Agribisnis). Bina Aksara, Jakarta.

Kotler Philip, 1984. Manajemen Pemasaran, Penerbit, PT.Intan Sejati Klaten,Indonesia.

Limbong W. H, 1987. Managemen Pemasaran Analisa Perencanaan dan Pengendalian. Airlangga, Jakarta.

Rodiosunu, 1980. Manajemen Pemasaran, Fakultas Ekonomi, UGM, Yogyakarta.

Saefuddin, 1981. Pemasaran Produk Pertanian dan Pengkajian Pemasaran Komoditi. Fakultas Pertanian. IPB, Bogor.

Soekartawi, 1999. Prinsip Dasar Manajemen Pertanian dan Aplikasi. Rajawali Pers, Jakarta. 